Original article

\title{
TYROSINE HYDROXYLASE POSITIVE NERVES AND MAST CELLS IN THE PORCINE GALLBLADDER
}

\author{
I. S. STEFANOV, A. P. VODENICHAROV, N. S. TSANDEV \& G. N. KOSTADINOV \\ Department of Veterinary Anatomy, Histology and Embryology, Faculty of \\ Veterinary Medicine, Trakia University, Stara Zagora, Bulgaria
}

\section{Summary}

Stefanov, I. S., A. P. Vodenicharov, N. S. Tsandev \& G. N. Kostadinov, 2017. Tyrosine hydroxylase positive nerves and mast cells in the porcine gallbladder. Bulg. J. Vet. Med., 20, No 1, 1-10.

The aim of this study was to detect the localisation of tyrosine hydroxylase (TH) positive nerve fibres (THN) and distribution of tyrosine hydroxylase positive mast cells (THMC) in the wall of porcine gallbladder. THN were observed as single fibres, nerve fibres forming perivascular plexuses and nerve fibres grouped within the nerve fascicles. In the gallbladder's fundus, body and neck, the $\mathrm{TH}^{+}$ fibres formed mucosal, muscular and serosal nonganglionated nerve plexuses. Toluidine blue (TB) staining was used to confirm that the TH positive cells were mast cells. The number of THMC in the propria of gallbladder`s fundus, body and neck was significantly higher than in the muscular and serosal layers in both genders. The number of mast cells in the musculature was higher than in the serosa. The density and location of the THMC were similar to the TB positive (with gamma metachromasia) mast cells in both males and females, and statistically significant difference was not established. In conclusion, original data concerning the existence and localisation of catecholaminergic nerves and THMC distribution in the porcine gallbladder's wall are presented. The results could contribute to the body of knowledge of functional communication between autonomic nerves and mast cells in the gallbladder.

Key words: autonomic nerves, gallbladder, mast cells, pig, tyrosine hydroxylase

\section{INTRODUCTION}

Tyrosine hydroxylase has been found by Nagatsu et al. (1964) in the brain, adrenal medulla, and sympathetically innervated organs. It specifically catalyses the conversion of L-tyrosine to 3,4-dihydroxyphenylalanine (DOPA) and requires tetrahydropteridine as a cofactor. Since it is generally thought that the reaction of tyrosine hydroxylase $(\mathrm{TH})$ is the initial and rate-limiting step of the catecholamine biosynthetic pathway, the enzyme would appear to play a central role in the regulation of catecholamine production (Levitt et al., 1965; Gordon et al., 2008). TH activity has been observed in many organs such as the adrenal glands, pancreas, liver, intestines, stomach, heart, brain, autonomic ganglia and pineal gland (Teitelman 
et al. 1981; Sternini \& Brecha, 1985; Goehler \& Sternini, 1991; Zhang et al. 1991; Oomori et al., 1994; Persson-Sjogren et al., 1998; Milner, 2004), and it is considered to regulate the blood flow and secretory activities in these tissues. Distribution of the nerve cells and fibres positive for tyrosine hydroxylase is investigated in detail in the different layers of the gallbladder's wall in humans (Mann et al., 1991; Uemura et al., 1997) and dogs (Mann et al., 1991). Based on the results, the authors conclude that most of the biliary sympathetic nerves are dopaminergic related both to the function of the smooth muscle cells and the epithelium. Sand et al. (1993) studied the expression and role of various neuropeptides (vasointestinal polypeptide, substance $\mathrm{P}$, bombesin, serotonin etc.) in the wall of the gallbladder and bile ducts in domestic swine except for the tyrosine hydroxylase.

Regarding the presence of dopamine in mast cells, there is evidence that it is described as an amine mediator in these cells in the organs of different animal species - in the liver, gut, lung, heart in ruminants (Falck et al., 1964), in the kidney of the domestic pig (Vodenicharov, 2008), and in cell cultures from rats (Freeman, 2001).

The lack of data about the presence of THN and THMC in porcine gallbladder and the important role of dopamine motivated us to perform that study with the aim to establish the distribution of mentioned nerves and cells for clearing the species features and their participation in the organ's function, as well.

\section{MATERIALS AND METHODS}

\section{Animals}

The material was obtained from the gallbladder's fundus, body and neck of 6 male and 6 female pigs (Landrace $\times$ Danube White), aged 6 months and weighing 92 $98 \mathrm{~kg}$, slaughtered for meat consumption in a slaughterhouse. All procedures were performed in accordance with the Directive 2010/63/EU of the European Parliament and of the Council of 22 September 2010 on the protection of animals used for scientific purposes.

\section{Light microscopic imunohistochemistry for tyrosine hydroxylase detection}

The tissue samples were immediately immersed in 4\% paraformaldehyde (Sigma Aldrich Chemie, Switzerland) in phosphate-buffered saline (PBS), $\mathrm{pH} 7.2$, for $24 \mathrm{~h}$ at $4{ }^{\circ} \mathrm{C}$. The samples were removed and soaked in solution of $15 \%$ sucrose in PBS overnight. Serial sections of $10 \mu \mathrm{m}$ thickness were prepared by means of a freezing microtome (Slee, Mainz, Germany). One part of them as free-floating sections were washed in PBS and preincubated in $0.03 \%$ Triton $\mathrm{X}-100$ in PBS for 10 minutes. Next step was the incubation of the sections in $1.2 \% \mathrm{H}_{2} \mathrm{O}_{2}$ in methanol for 10 minutes. After washing in $0.03 \%$ Triton $X-100$ in PBS, the sections were incubated in $2 \%$ bovine serum albumin in PBS for 20 minutes, followed by brief washing in PBS. The sections were incubated for $48 \mathrm{~h}$ with the primary rabbit polyclonal antibody (anti-tyrosine hydroxylase antibody - neuronal marker ab41528, Abcam, UK). Then incubation with secondary anti-rabbit biotinylated antibody (Vector, Burlingame, CA 94010, USA) was performed, followed by incubation with avidin-biotin-peroxidae complex (VECTASTAIN ABC Reagent, Vector, Burlingame, CA 94010, USA). After washing in PBS, the reaction was visualised by 3,3'-diaminobenzidine (DAB) (liquid $\mathrm{DAB}+$ Substrate-Chromogen System, DAKO; K3468, Glostrup, Denmark). 
Sections incubated with non-immune sera instead of the primary antibody were used as negative controls.

Depending on the degree of the immunostaining in brown, the microscopic assessment of the reaction was scored as absent, weak, moderate and strong.

Light microscopic histochemistry for mast cell metachromasia

Additional serial sections were used for histochemical staining with $0.1 \%$ solution of toluidine blue in McIlvane's buffer, $\mathrm{pH}$ 3 to detect metachromasia in the mast cells (Pearce, 1960).

\section{Statistical analysis}

Cross serial sections of the gallbladder's fundus, body and neck of each animal were used. On five sections from each part of gallbladder, ten fields with an area of $1 \mathrm{~mm}^{2}$ were studied by light microscope (ZEISS Primo Star, Germany), camera (Progres, Capture 2.6 - JENOPTIK) and software analysis programme (Soft Imaging System $\mathrm{GmbH}$ ). The data for mast cells density (number $/ \mathrm{mm}^{2}$ ) are presented as mean \pm SD. Statistical data processing was done by using Student's $t$-test. The difference was considered significant at $\mathrm{P}<0.05$.

\section{RESULTS}

Light microscopic observations showed that in the wall of gallbladder's fundus, body and neck, THN formed mucosal, muscular and serosal nonganglionated nervous plexuses (Table 1). In the lamina propria, single adrenergic fibres (from 2.03 to $2.09 \mu \mathrm{m}$ in diameter) predominated but some of them formed thin nerve bundles, which diameter increased from $3.53 \mu \mathrm{m}$ in the fundus to $8.73 \mu \mathrm{m}$ in the neck of gallbladder, and showed weak to moderate reactivity, reaching the basement membrane of mucosal layer. These nerve structures formed well developed but less dense nervous plexus than in the muscular layer (Fig. 1). Intraepithelial localisation of catecholaminergic nerves was not observed. Immunopositive nerve fibres were also observed around the glands of the gallbladder's neck. The nervous plexuses in different layers were interconnected by nerve bundles.

In the muscular layer, nerve bundles containing THN were significantly thicker than in the propria and thinner than in the serosa. They exhibited moderate to strong immunoreactivity and formed well developed and dense nervous plexus. The catecholaminergic nerve fibres were located predominantly near the blood vessels and were arranged in perivascular and paravascular nervous plexus. In the arterial wall, THN were localised mainly in the adventitia and between adventitia and tunica media. Perivascular THN were significantly thicker in the arterial adventitia than the nerves located near the media. In the adventitia of veins, single THN were also seen.

In the serosal layer, THN formed the thickest nerve bundles arranged in nonganglionated nervous plexus (Table 1). Nerve bundles observed in the adventitia of the branches of $A$. cystica were thicker than those between adventitia and media. Para- and periarterial THN detected in the gallbladder's serosa were significantly thicker than in the muscular layer (Table 1).

We did not found a statistical significant difference in the number of mast cells as well as in the diameter of nerve bundles in the wall of porcine gallbladder between males and females, i.e. sexual dimorphism was not established.

The localisation and density of THMC in lamina propria mucosae, tunica mus- 
cularis and tunica serosa of the porcine gallbladder's wall were established.

Light microscopic immunohistochemistry showed medium to strong enzyme reactivity in the positive granules of $\mathrm{TH}$ cells (Fig. 2a). We found that the morphology and localisation of the THMC was similar to the TBMC (Fig. 2a, b and Fig. $3 a, b)$. In the lamina propria of the gallbladder, most THMC were located close to the vessels of the microcirculatory bed and near the basement membrane of biliary lining epithelium. In the gallbladder neck, mast cells were also observed near the glands, as well as in and around the lymph nodules (Fig. 3a, b). Some of mast cells were localised near the catecholaminergic nerve fibres in all lay-

Table 1. Diameter of tyrosine hydroxylase (TH) positive nerve fibres in the different layers of gallbladder's fundus, body and neck. Data are presented as mean \pm SD (min-max range)

\begin{tabular}{|c|c|c|}
\hline \multirow{2}{*}{ TH nerves localisation } & \multicolumn{2}{|c|}{ TH nerves diameter, $\mu \mathrm{m}$} \\
\hline & male pigs $(n=6)$ & female pigs $(n=6)$ \\
\hline \multicolumn{3}{|l|}{ Gallbladder fundus } \\
\hline lamina propria mucosae & $2.90 \pm 0.50^{\&}(2.03-3.53)$ & $2.97 \pm 0.52^{\&}(2.09-3.70)$ \\
\hline tunica muscularis & $25.42 \pm 8.89 *(14.4-39.8)$ & $26.04 \pm 8.81 *(15.21-40.80)$ \\
\hline -paraarterial nerves & $10.93 \pm 0.54^{\mathrm{A}}(9.51-11.92)$ & $10.96 \pm 0.61^{\mathrm{A}}(9.83-12.62)$ \\
\hline -periarterial nerves & $1.96 \pm 0.09^{\mathrm{B}}(1.82-2.10)$ & $2.04 \pm 0.13^{\mathrm{B}}(1.92-2.42)$ \\
\hline \multicolumn{3}{|l|}{ tunica serosa } \\
\hline -paraarterial nerves & $66.12 \pm 3.39^{\mathrm{A}}(59.93-71.82)$ & $66.68 \pm 3.35^{\mathrm{A}}(60.07-72.06)$ \\
\hline -periarterial nerves & $24.59 \pm 2.06^{\mathrm{B}}(22.03-28.08)$ & $21.75 \pm 5.32^{\mathrm{B}}(15.27-28.48)$ \\
\hline $\begin{array}{l}\text {-border between adventitia } \\
\text { and media }\end{array}$ & $4.41 \pm 1.80^{\mathrm{C}}(1.83-8.32)$ & $4.50 \pm 1.79^{\mathrm{C}}(1.94-8.49)$ \\
\hline \multicolumn{3}{|l|}{ Gallbladder body } \\
\hline lamina propria mucosae & $3.05 \pm 0.68^{\&}(2.09-5.20)$ & $3.15 \pm 0.69^{\&}(2.17-5.53)$ \\
\hline tunica muscularis & $15.52 \pm 7.09 *(7.01-27.51)$ & $15.62 \pm 7.06 *(7.13-27.51)$ \\
\hline -paraarterial nerves & $10.84 \pm 0.55^{\mathrm{A}}(9.84-11.83)$ & $11.04 \pm 0.46^{\mathrm{A}}(10.04-11.74)$ \\
\hline -periarterial nerves & $1.96 \pm 0.11^{\mathrm{A}}(1.79-2.17)$ & $2.10 \pm 0.17^{\mathrm{A}}(1.90-2.58)$ \\
\hline \multicolumn{3}{|l|}{ tunica serosa } \\
\hline -paraarterial nerves & $52.45 \pm 7.92^{\mathrm{A}}(39.75-63.77)$ & $53.03 \pm 7.72^{\mathrm{A}}(40.28-63.92)$ \\
\hline -periarterial nerves & $29.92 \pm 4.10^{\mathrm{B}}(24.64-39.04)$ & $30.48 \pm 3.98^{\mathrm{B}}(25.28-38.92)$ \\
\hline $\begin{array}{l}\text {-border between adventitia } \\
\text { and media }\end{array}$ & $5.02 \pm 1.63^{\mathrm{C}}(1.92-8.12)$ & $5.19 \pm 1.68^{\mathrm{C}}(2.02-8.82)$ \\
\hline \multicolumn{3}{|l|}{ Gall bladder neck } \\
\hline lamina propria mucosae & $4.91 \pm 2.16^{\&}(2.09-8.73)$ & $4.82 \pm 1.85^{\&}(2.28-8.02)$ \\
\hline tunica muscularis & $20.63 \pm 12.45 *(7.36-36.14)$ & $21.17 \pm 12.24 *(7.28-37.29)$ \\
\hline -paraarterial nerves & $10.83 \pm 1.13^{\mathrm{A}}(8.73-12.73)$ & $11.01 \pm 0.91^{\mathrm{A}}(9.93-12.47)$ \\
\hline -periarterial nerves & $1.81 \pm 0.09^{\mathrm{B}}(1.62-1.99)$ & $1.82 \pm 0.08^{\mathrm{B}}(1.68-1.94)$ \\
\hline \multicolumn{3}{|l|}{ tunica serosa } \\
\hline -paraarterial nerves & $53.18 \pm 7.48^{\mathrm{A}}(8.84-62.52)$ & $53.64 \pm 7.25^{\mathrm{A}}(40.26-64.09)$ \\
\hline -periarterial nerves & $30.06 \pm 2.42^{\text {B }}(25.73-34.82)$ & $30.40 \pm 2.88^{\text {B }}(25.03-36.02)$ \\
\hline $\begin{array}{l}\text {-border between adventitia } \\
\text { and media }\end{array}$ & $4.87 \pm 1.33^{\mathrm{C}}(2.54-7.94)$ & $5.15 \pm 1.20^{\mathrm{C}}(3.29-8.38)$ \\
\hline
\end{tabular}




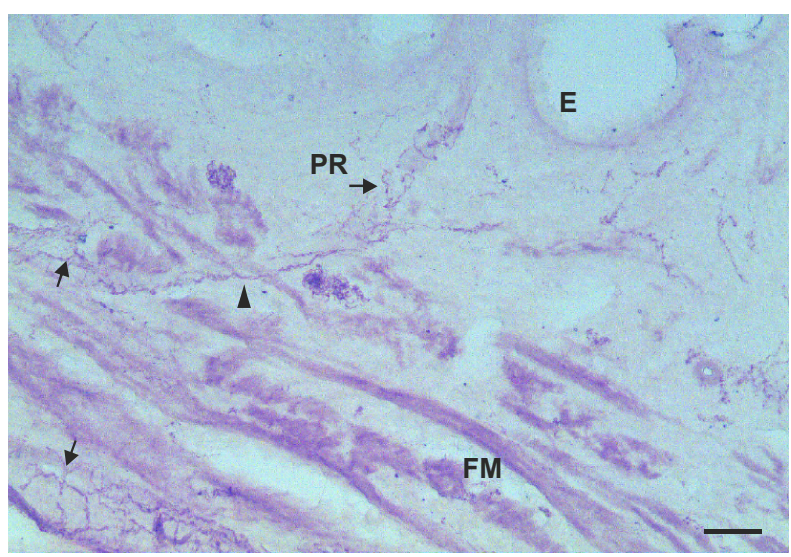

Fig. 1. Muscular and serosal nonganglionated nervous plexuses consisting of tyrosine hydroxylase positive nerve fascicles (arrows). The nervous plexuses situated in the different layers of the gallbladder's body are interconnected by nerve bundles (arrowhead). E-epithelium of the gallbladder, PR-propria, FM-muscular layer. Bar $=60 \mu \mathrm{m}$.
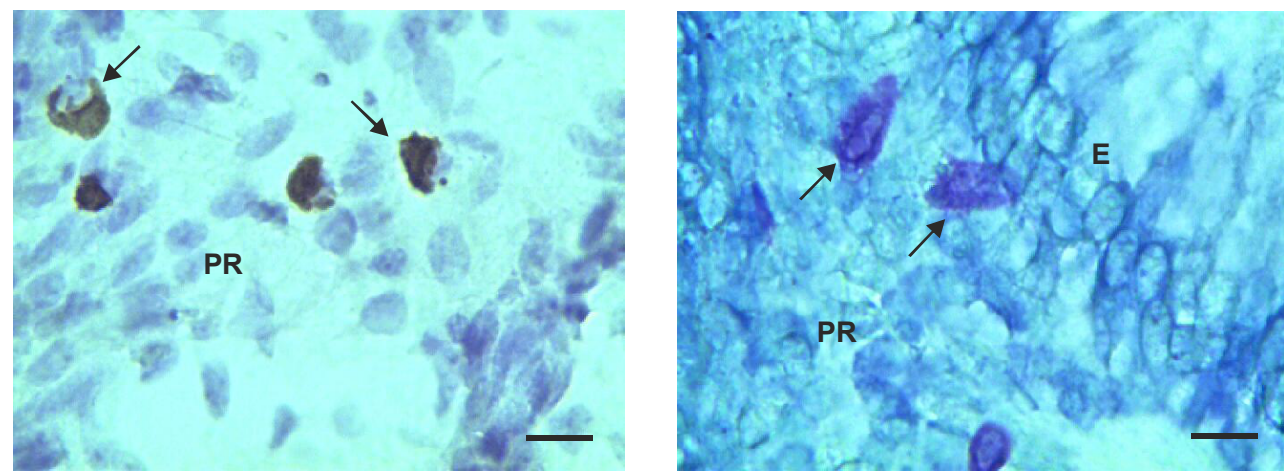

Fig. 2 A. Medium to strong enzyme reactivity in the positive granules of mast cells (arrows); B. The morphology of metachromatically stained mast cells (arrows) is similar to that of the tyrosine hydroxylase positive mast cells. E - gallbadder epithelium,

$\mathrm{PR}$ - propria of the gallbladder`s neck. Bar $=15 \mu \mathrm{m}$.

ers of the organ (Fig. 4). In the fibromuscular and serosal layers, the same cells were observed predominantly in the vicinity of blood vessels. THMC were also detected between the smooth muscle bundles of fibromuscular layer and close to the $\mathrm{TH}$ positive nerve fibres. THMC were also observed in the adventitial layer of arteries and veins.

THMC density and localisation were the same as those of TBMC cells in both males and females and statistical significant difference was not observed (Table 2).

\section{DISCUSSION}

In the current study, the presence of $\mathrm{TH}$ autonomic nerves as well as THMC in the wall of porcine gallbladder was identified for the first time. Since this enzyme catalyses the rate-limiting step in the biosyn- 

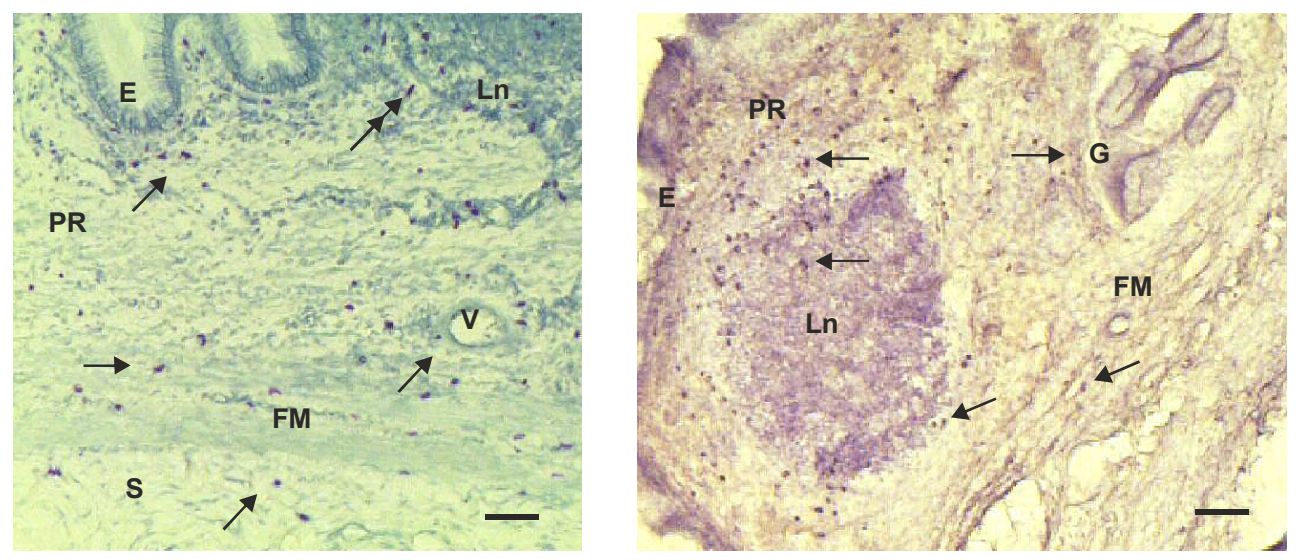

Fig. 3 A. Toluidine blue positive mast cells (arrows) in the propria (PR), muscular (FM) and serosal (S) layers (bar $=60 \mu \mathrm{m}$ ); B. Tyrosine hydroxylase positive mast cells (arrows) with a localisation similar to that of the toluidine blue positive mast cells. E - epithelium of the gallbladder's neck, $\mathrm{V}$ - venule, $\mathrm{Ln}$ - lymph nodule, $\mathrm{G}$ - glands in the gallbladder's neck (bar $=50 \mu \mathrm{m})$.

thesis of catecholamines in sympathetic nerve fibres (Levitt et al., 1965) it can be used as a marker for these nerve fibres (Goldstein et al., 1973). Sympathetic innervation of the gallbladder has been investigated in detail in guinea pigs. The gallbladder contains abundant sympathetic postganglionic nerve fibres that arise from the celiac and superior mesenteric ganglia. Catecholamine histofluorescence and immunohistochemical detection of $\mathrm{TH}$ and dopamine beta hydroxylase have been used to identify the sympathetic postganglionic nerves in the wall of the gallbladder (Cai \& Gabella, 1983; 1984; Mawe \& Gershon, 1989). According to Balemba et al. (2004) TH positive neurons in the gallbladder were relatively small. However, Chen et al. (1998) considered that the sympathetic neurotransmission is the principal source of inhibitory neural input to the gallbladder smooth muscles, causing decreased gallbladder tone, and may contribute to the filling of the organ.

In the current study $\mathrm{TH}$ positive nerve fibres were observed as single fibres, nerve fibres forming perivascular plexuses and nerve fibres grouped into nerve fascicles, which correlates with the results of Forsgren \& Söderberg (1987) regarding the distribution of the mentioned nerves in the guinea pig and bovine heart. Our findings indicate that the nerve supply of gallbladder in swine was similar to those of guinea pig gallbladder, described by Cai \& Gabella (1983). The organisation of nerve structures corresponded to well developed ganglionated and nonglanglionated nerve plexuses in the lamina propria, tunica muscularis and tunica serosa as well as peri- and paravascular nerve plexuses along the cystic artery branches. However, in swine unlike the guinea pig, the nonglanglionated nerve plexus situated in the propria and in the muscle layer was well developed. With regard to the human and canine gallbladders, Mann et al. (1991) found out that the vessels, the organ musculature and the intramural ganglion cells receive a substantial sympathetic innervation in both species, whereas the mucosa appears to be supplied almost entirely by non-sympathetic fibres. 


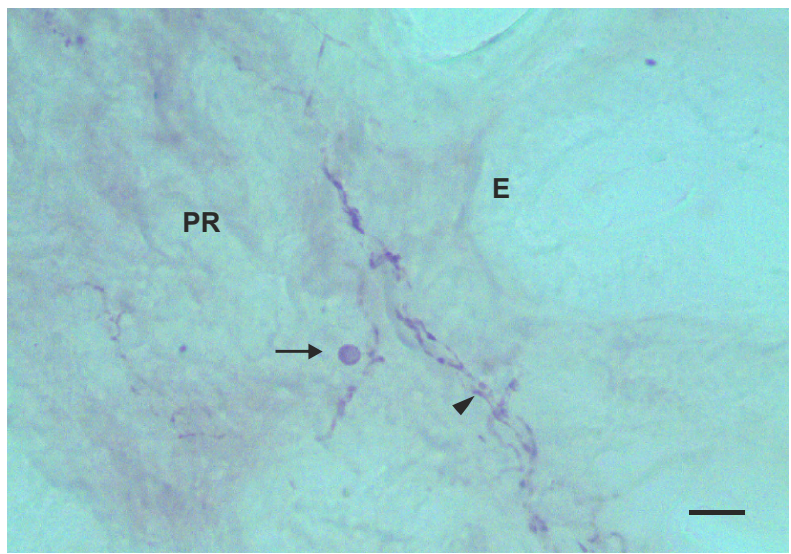

Fig. 4. Tyrosine hydroxylase positive mast cells (arrow) near the catecholaminergic nerve fibres (arrowhead) in the propria (PR) of gallbladder's body. E - epithelium of the gallbladder. Bar $=20 \mu \mathrm{m}$.

Table 2. Density (number $/ \mathrm{mm}^{2}$ ) of tyrosine hydroxylase (TH) positive and toluidine blue (TB) positive mast cells (TBMC) in the different layers of gallbladder (mean $\pm \mathrm{SD} ; \mathrm{n}=6$ ).

\begin{tabular}{lcccc}
\hline Mast cell localisation & \multicolumn{2}{c}{ TH-positive mast cells } & \multicolumn{2}{c}{ TB-positive mast cells } \\
\cline { 2 - 5 } & male $(\mathrm{n}=6)$ & female $(\mathrm{n}=6)$ & male $(\mathrm{n}=6)$ & female $(\mathrm{n}=6)$ \\
\hline Gallbladder fundus & & & & \\
lamina propria mucosae & $42.11 \pm 5.04^{\mathrm{A}}$ & $42.31 \pm 5.06^{\mathrm{A}}$ & $42.68 \pm 5.28^{\mathrm{A}}$ & $43.30 \pm 5.76^{\mathrm{A}}$ \\
tunica muscularis & $22.38 \pm 2.84^{\mathrm{B}}$ & $22.68 \pm 2.93^{\mathrm{B}}$ & $23.18 \pm 2.47^{\mathrm{B}}$ & $23.95 \pm 2.10^{\mathrm{B}}$ \\
tunica serosa & $22.70 \pm 3.16^{\mathrm{B}}$ & $23.16 \pm 3.18^{\mathrm{B}}$ & $22.91 \pm 2.99^{\mathrm{B}}$ & $23.55 \pm 2.88^{\mathrm{B}}$ \\
\hline Gallbladder body & & & & \\
lamina propria mucosae & $42.91 \pm 4.16^{\mathrm{A}}$ & $42.88 \pm 4.16^{\mathrm{A}}$ & $43.36 \pm 4.10^{\mathrm{A}}$ & $43.90 \pm 4.03^{\mathrm{A}}$ \\
tunica muscularis & $33.78 \pm 8.40^{\mathrm{B}}$ & $34.02 \pm 8.34^{\mathrm{B}}$ & $34.10 \pm 8.29^{\mathrm{B}}$ & $34.38 \pm 8.24^{\mathrm{B}}$ \\
tunica serosa & $23.18 \pm 2.42^{\mathrm{C}}$ & $23.36 \pm 2.55^{\mathrm{C}}$ & $23.26 \pm 2.52^{\mathrm{C}}$ & $24.15 \pm 2.49^{\mathrm{C}}$ \\
\hline Gallbladder neck & & & & \\
lamina propria mucosae & $47.31 \pm 2.37^{\mathrm{A}}$ & $47.58 \pm 2.31^{\mathrm{A}}$ & $41.27 \pm 6.43^{\mathrm{A}}$ & $44.25 \pm 6.12^{\mathrm{A}}$ \\
tunica muscularis & $34.06 \pm 10.27^{\mathrm{B}}$ & $34.18 \pm 9.96^{\mathrm{B}}$ & $34.83 \pm 9.47^{\mathrm{B}}$ & $36.85 \pm 9.16^{\mathrm{B}}$ \\
tunica serosa & $22.73 \pm 2.75^{\mathrm{C}}$ & $23.25 \pm 2.93^{\mathrm{C}}$ & $22.88 \pm 2.33^{\mathrm{C}}$ & $24.55 \pm 2.24^{\mathrm{C}}$ \\
\hline
\end{tabular}

different superscripts within the same layer denote statistically significant differences at $\mathrm{P}<0.001$.

The role of THN in porcine gallbladder's wall can be explained having in mind other studies about the innervation of gallbladder in guinea pigs, dogs, humans (Mawe et al., 2001) and cats (Chen et al., 1998). These data are consistent with several reports, indicating that stimulation of sympathetic nerves can result in gallbladder relaxation. In the guinea pig,
THN are restricted to the vascular plexus and the ganglionated plexuses. However, in dogs and humans, these nerves are also distributed throughout the muscular layer, where locally released catecholamines can act directly on $\beta$-adrenoreceptors to relax the musculature (Mawe et al., 2001).

In the wall of porcine gallbladder, $\mathrm{TH}$ expression was also observed in mast cells 
granules. These results correlate with those of Rönnberg et al. (2012), who found that the granular localisation of the enzyme is due to its interaction with serglicin. The same authors detected the TH expression in both mucosal and connective tissue type mast cells. Although the function of the mast cell dopamine has not yet been precisely determined, Rönnberg et al. (2012) presented a number of options of biological significance. Dopamine is known as a neurotransmitter, therefore dopamine released from the mast cells may be has neurotransmitter function (Stead et al., 1989). Signal input from mast cells to intrinsic enteric neurons is particularly crucial, because the enteric nervous system fulfills a pivotal role in the control of gastrointestinal functions. Activated enteric neurons are able to generate alterations in motility and secretion. Mast cell signalling to extrinsic nerve fibres takes part in pathways generating visceral pain or extrinsic reflexes contributing to the disturbed motor and secretory function (Boeckxstaens, 2006; Rijnierse et al., 2007; Van Nassauw et al., 2007; Kraneveld et al., 2008). Based on the reports of the mentioned authors and the results of the current study we suggested that the localisation of mast cells near the nervous structures in porcine gallbladder wall was very similar to those in the gut wall, and most probably the same neuroimmune interaction was present. Further basic and clinical research is needed to confirm our assumptions.

The observed localisation of mast cells within and around the lymph nodules of porcine gallbladder can be explained by their influence on lymphocyte proliferation, for which the data are contradictory as other authors reported. For example, Cook-Mills et al. (1995), established that the involvement of dopamine receptors on lymphocytes suppressed lymphocyte proliferation but according to Tsao et al. (1997), the involvement of dopamine receptor increased lymphocyte proliferation. Some studies have shown that dopamine can affect neutrophil function (Derevenco et al., 1992) and activate macrophages (Gomez et al., 1999). This indicates that dopamine released from mast cells may have a great influence on the functional properties of other immune cells, which adds a new dimension to the role of mast cells in the fine tuning of the immune system.

In conclusion, using immunohistochemical staining, we present original data concerning the existence and localisation of catecholaminergic nerves and THMC in porcine gallbladders wall. This finding proved that in the studied organ, there were two sources of catecholamines: autonomic nerves and mast cells.

\section{REFERENCES}

Balemba, O., M. J. Salter \& G. M. Mawe, 2004. Innervation of the extrahepatic biliary tract. The Anatomical Record, 280A, 836-847.

Boeckxstaens, G. E., 2006. Neuroimmune interaction in the gut: From bench to bedside. Verhandelingen - Koninklijke Academie Voor Geneeskunde Van Belgie, 68, 329-355.

Cai, W. \& G. Gabella, 1983. Innervation of the gallbladder and biliary pathways in the guinea pig. Journal of Anatomy, 136, 97109.

Cai, W-Q. \& G. Gabella, 1984. Catecholamine-containing cells in the nerve plexus of the guinea pig gallbladder. Acta Anatomica, 119,10-17.

Chen, Q., K. Lee, Z. Xiao, P. Biancani \& J. Behar, 1998. Mechanism of gallbladder relaxation in the cat: Role of norepinephrine. 
Journal of Pharmacology and Experimental Therapeutics, 285, 475-479.

Cook-Mills, J. M., R. L. Cohen, R. L. Perlman \& D. A. Chambers, 1995. Inhibition of lymphocyte activation by catecholamines: evidence for a non-classical mechanism of catecholamine action. Immunology, 85, 544-549.

Derevenco, P., C. Marina, T. Pavel, A. O1teanu, M. Junie \& I. Baciu, 1992. Phagocytic response in rats following chemical sympathectomy with 6-hydroxydopamine. Revue Roumaine de Physiologie, 29, 5762.

Anonymous, 2010. EC Directive 2010/63/EU of the European Parliament and of the Council of 22 September 2010 on the protection of animals used for scientific purposes. Official Journal of the European Union, L 276, 33-79.

Falck, B., T. Nystedt, E. Rosengren \& J. Stenflo, 1964. Dopamine and mast cells in ruminants. Acta Pharmacologica et Toxicologica, 21, 51-58.

Forsgren, S. \& L. Söderberg, 1987. Immunohistochemical procedures for the demonstration of peptide- and tyrosine hydroxylase-containing nerve fibers in cryostat sections of unfixed rapidly frozen tissue stored for long periods of time. A study on heart tissue. Histochemistry, 87, 561-568.

Freeman, J., J. Ryan, C. P. Shelburne, D. P. Bailey, L. A. Bouton, N. Narasimhachari, N. Siméon, F. Couderc \& J. K. Stewart, 2001. Catecholamines in murine bone marrow derived mast cells. Journal of Neuroimmunology, 119, 231-238.

Goehler, L. E. \& C. Sternini, 1991. Neuropeptide $\mathrm{Y}$ immunoreactivity in the mammalian liver: pattern of innervation and coexistence with tyrosine hydroxylase immunoreactivity. Cell Tissue Research, 265, 287 295.

Goldstein, M., B. Anagoste, L. S. Freedman, M. Roffman, R. P. Ebstein, D. H. Park, K. Fuxe \& T. Hökfelt, 1973. Characterization, localization and regulation of catecholamine synthesizing enzymes. In: Frontiers in Catecholamine Research, eds E. Usdin \& S. H. Snyder, Pergamon Press, New York, USA. pp. 69-81.

Gomez, F., P. Ruiz, F. Briceno, C. Rivera \& R. Lopez, 1999. Macrophage Fc $\gamma$ receptors expression is altered by treatment with dopaminergic drugs. Clinical Immunology (Orlando), 90, 375-387.

Gordon, S. L., N. S. Quinsey, P. R. Dunkley \& P. W. Dickson, 2008. Tyrosine hydroxylase activity is regulated by two distinct dopamine-binding sites. Journal of Neurochemistry, 106, 1614-1623.

Kraneveld, A. D., A. Rijnierse, F. P. Nijkamp \& J. Garssen, 2008. Neuro-immune interactions in inflammatory bowel disease and irritable bowel syndrome: Future therapeutic targets. European Journal of Pharmacology, 585, 361-374.

Levitt, M., S. Spector, A. Sjoerdsma \& S. Udenfriend, 1965. Elucidation of the ratelimiting step in norepinephrine biosyntesis in perfused guinea pig heart. Journal of Pharmacology and Experimental Therapeutics, 148, 1-8.

Mann, R., P. S. Bhathal \& C. Bell, 1991. Aminergic innervation of the gall bladder in man and dog. Clinical Autonomic Research, 1, 205-213.

Mawe, G. \& M. D. Gershon, 1989. Structure, afferent innervation, and transmitter content of ganglia of the guinea pig gallbladder: Relationship to the enteric nervous system. Journal of Comparative Neurology, 283, 374-390.

Mawe, G. M. \& L. M. Ellis, 2001. Chemical coding of intrinsic and extrinsic nerves in the guinea pig gallbladder: Distributions of PACAP and orphanin FQ. The Anatomical Record, 262, 101-109.

Milner, T. A., 2004. Ultrastructural localization of tyrosine hydroxylase immunoreactivity in the rat diagonal band of broca. Journal of Neuroscience Research, 30, 498-511.

Nagatsu, T., M. Levitt \& S. Udenfriend, 1964. Tyrosine hydroxylase. The initial step in 
norepinephrine biosyntesis. Journal of Biological Chemistry, 239, 2910-2917.

Oomori, Y., H. Iuchi, K. Ishikawa, Y. Satoh \& K. Ono, 1994. Immunocytochemical study of tyrosine hydroxylae and dopaminehydroxylase immunoreactivities in the rat pancreas. Histochemistry, 101, 313-323.

Pearce, A., 1960. Histochemistry, $2^{\text {nd }}$ edn, J.\&A. Churchill Ltd., London, pp. 692.

Persson-Sjogren, S., S. Forsgren \& I. B. Taljedal, 1998. Expression of tyrosine hydroxylase, calcitonin gene-related peptide, substance $\mathrm{P}$ and protein gene product 9.5 in mouse islets transplanted under the kidney capsule. Neuropeptides, 32, 307-318.

Rijnierse, A., F. P. Nijkamp \& A. D. Kraneveld, 2007. Mast cells and nerves tickle in the tummy: implications for inflammatory bowel disease and irritable bowel syndrome. Pharmacology \& Therapeutics, 116, 207-235.

Rönnberg, E., G. Calounova \& G. Pejler, 2012. Mast cells express tyrosine hydroxylase and store dopamine in a serglycindependent manner. Biological Chemistry, 393, 107-112.

Stead, R. H., M. F. Dixon, N. H. Bramwell, R. H. Riddell \& J. Bienenstock, 1989. Mast cells are closely apposed to nerves in the human gastrointestinal mucosa. Gastroenterology, 97, 575-585.

Sternini, C. \& N. Brecha, 1985. Distribution and colocalization of neuropeptide $\mathrm{Y}$ and tyrosine hydroxylase-like immunoreactivity in the guinea-pig heart. Cell and Tissue Research, 241, 93-102.

Sand, J., H. Tainio \& I. Nordback, 1993. Neuropeptides in pig sphincter of Oddi, bile duct, gallbladder, and duodenum. Digestive Diseases and Sciences, 38, 694-700.

Teitelman, G., T. H. Joh \& D. J. Reis, 1981. Transformation of catecholaminergic precursors into glucagons (A) cells in mouse embryonic pancreas. Proceedings of the National Academy of Sciences of the United States of America, 78, 5225-5229.
Tsao, C.W., Y.S. Lin \& J.T. Cheng, 1997. Effect of dopamine on immune cell proliferation in mice. Life Sciences, 61, 361371.

Uemura, S., S. Pompolo, J. B. Furness \& K. J. Hardy, 1997. Nitric oxide synthase in neurons of the human gall-bladder and its colocalization with neuropeptides. Journal of Gastroenterology and Hepatology 12, 257-265.

Van Nassauw, L., D. Adriaensen \& J.P. Timmermans, 2007. The bidirectional communication between neurons and mast cells within the gastrointestinal tract. Autonomic Neuroscience, 133, 91-103.

Vodenicharov, A., 2008. Morphological investigations on the role of mast cells mediators, other vasoactive substances and the glomerular arterioles in the renal hemodynamics of domestic swine. DSc Dissertation, Faculty of Veterinary Medicine, Trakia University, Stara Zagora, pp. 77197 (BG).

Zhang, E-T., J. D. Mikkelsen \& M. Moller, 1991. Tyrosine hydroxylase- and neuropeptide Y-immunoreactive nerve fibers in the pineal complex of untreated rats and rats following removal of the superior cervical ganglia. Cell and Tissue Research, 265, 63-71.

Paper received 02.12.2015; accepted for publication 26.02.2016

\section{Correspondence:}

Ivaylo S. Stefanov, PhD

Department of Veterinary Anatomy,

Histology and Embryology,

Faculty of Veterinary Medicine,

Trakia University, 6000 Stara Zagora, Bulgaria; tel: +359 42699650 ;

e-mail: iv_stefanov@uni-sz.bg 